TRADE AND PRODUCTION NETWORKS

OF U.S. MNCs AND EXPORTS BY

THEIR ASIAN AFFILIATES

Robert E. Lipsey

Working Paper 5255 


\title{
TRADE AND PRODUCTION NETWORKS \\ OF U.S. MNCS AND EXPORTS BY \\ THEIR ASIAN AFFILIATES
}

Robert E. Lipsey

Working Paper 5255

\author{
NATIONAL BUREAU OF ECONOMIC RESEARCH \\ 1050 Massachusetts Avenue \\ Cambridge, MA 02138 \\ September 1995
}

This paper is the product of a grant to the National Bureau of Economic Research by the Chiang Ching-kuo Foundation for International Scholarly Exchange for a study of "Changing Methods of Taiwan's Entry into World Markets." I am indebted to the Foundation for its support and to Dale Shannon of the Bureau of Economic Analysis for valuable assistance with the BEA data. This paper is part of NBER's research program in International Trade and Investment. Any opinions expressed are those of the author and not those of the National Bureau of Economic Research.

(C) 1995 by Robert E. Lipsey. All rights reserved. Short sections of text, not to exceed two paragraphs, may be quoted without explicit permission provided that full credit, including $\odot$ notice, is given to the source. 


\title{
TRADE AND PRODUCTION NETWORKS \\ OF U.S. MNCs AND EXPORTS BY \\ THEIR ASIAN AFFILIATES
}

\begin{abstract}
Network connections within MNCs seem to improve export market shares for Asian affiliates of those MNCs. In particular, Asian affiliates of U.S. MNCs export more to markets where their parent firms' exports to affiliates are larger, and less to markets where their parent firms export more to non-affiliates. However, the latter effect is much smaller per dollar of parent exports. These relationships are fairly consistent across industries and markets, across markets within two industries, across industries for two affiliate home countries, and across exporters and industries for individual markets.
\end{abstract}

Robert E. Lipsey

National Bureau of Economic Research

269 Mercer Street, 8th Floor

New York, NY 10003 
Trade and Production Networks of U.S. MNCs and Asian Affiliate Exports Robert E. Lipsey

\section{Introduction}

One of the benefits that host countries hope for from inward direct investment is that it gives firms producing within their borders greater access to worldwide markets by linking them into the trading networks of the investing MNCs. There is little empirical evidence for this expectation because few investing countries collect any data on the trade of their firms' foreign affiliates. The United States is the only one that collects fairly comprehensive data on the amount and direction of exports by affiliates of its MNCs .

In this paper we use these data to ask whether exports to a country by Asian affiliates of U.S. multinationals are affected by the activity in the importing country of other members of a multinational network. That activity is defined broadly here to include both exports to the country by the parent of the Asian affiliate and production in that country by other affiliates of the same parent.

\section{Affiliate Export Equations without Network Affillate Variables}

We begin by trying to explain exports by U.S.-owned Asian affiliates to particular destinations by the characteristics of the importing regions, ignoring the extent, if any, of related parent or affiliate activity. Ideally we would wish to have a detailed list of affiliate export destinations. Unfortunately, the BEA survey for 1989 that is the basis for our study lists as destinations only three specific countries other than the United States (Canada, the United Kingdom, and Japan) and six broad regions excluding the 
three countries (U.S. Department of Commerce, 1992). We have constructed, for these nine export destinations, measures of population, and nominal and real GDP, as would be done in a gravity model of trade, and the value of imports from all sources, classified by industry. The population and income data represent elements of total demand for goods and the value of imports, by industry, are intended to reflect both the composition of demand and the openness of each region to imports in general and to imports in each industry. We did not attempt to include distance measures because some of the destination regions were so broad.

The Asian exporters for which we have made these calculations include U.S. affiliates in Hong Kong, Singapore, South Korea, and Taiwan, and also Indonesia, Malaysia, and Thailand. The numbers of U.S. affiliates range from only seven in Indonesia to 175 in Singapore.

The dependent variable in these equations is exports by an individual Asian manufacturing affiliate of a U.S. parent to a region of the world. Each affiliate is tagged with an industry according to its major activity, and the imports into the destination region that are the independent variable are the imports for each exporting affiliate's industry.

of the 34 manufacturing industries in the BEA classification, 27 appear in these Asian countries, but the distribution across industries is very uneven. Of the 499 affiliates, 187 are in Electrical and Electronic Machinery and Equipment, mostly in Electronic components and accessories, and 104 are in Non-electrical Machinery, mainly office and computing machinery.

A few equations along these lines are shown in Table 1 . Coefficients for imports into the region in the exporting affiliate's industry are always positive and significant, as are those for population and real GDP, while 
Table 1

Equations Explaining Exports to a Region by a U.S.-owned Asian Affiliate by Region Characteristics

\begin{tabular}{|c|c|c|c|c|c|c|c|c|}
\hline \multirow{2}{*}{$\begin{array}{l}\text { Eq. } \\
\text { No }\end{array}$} & \multicolumn{6}{|c|}{ Independent Variables } & \multirow{2}{*}{$\begin{array}{c}\text { Constant } \\
\text { Term }\end{array}$} & \multirow[b]{2}{*}{$\overline{\mathbf{R}}^{2}$} \\
\hline & (POP(L) & $\operatorname{NGDP}(\mathrm{L})$ & CNDGP (L) & RGDP (L) & CRGDP(L) & $\operatorname{IMP}(\mathrm{KL})$ & & \\
\hline $1-1$ & $\begin{array}{r}5.11 \\
(3.5)\end{array}$ & $\begin{array}{l}-2.83 \\
(0.2)\end{array}$ & & & & $\begin{array}{r}4.79 \\
(3.2)\end{array}$ & $\begin{array}{r}2.02 \\
(0.7)\end{array}$ & .064 \\
\hline $1-2$ & $\begin{array}{c}6.41 \\
(2.97)\end{array}$ & & $(0.7)$ & & & $\begin{array}{r}4.51 \\
(3.6)\end{array}$ & $\begin{array}{l}-1.18 \\
(0.3)\end{array}$ & .065 \\
\hline $1-3$ & & & & $\begin{array}{r}2.75 \\
(3.4)\end{array}$ & & $\begin{array}{r}3.32 \\
(2.4)\end{array}$ & $\begin{array}{r}-.51 \\
(0.2)\end{array}$ & .058 \\
\hline $1-4$ & & & & & $\begin{array}{l}-.421 \\
(2.6)\end{array}$ & $\begin{array}{r}5.33 \\
(3.9)\end{array}$ & $\begin{array}{r}9.93 \\
(3.9)\end{array}$ & .054 \\
\hline
\end{tabular}

No. of Observations: 499

t-statistics in parentheses 
coefficients for nominal GDP and real GDP per capita are negative and the latter is significant.

Among these independent variables, population and nominal GDP are positively correlated. GDP per capita, which is GDP divided by population, is strongly and negatively correlated with population. Per capita GDP and population should not, therefore, be in the same equation.

Although there are significant positive coefficients for both population and industry imports, these equations do not explain much of the variation in affiliate exports. Industry imports alone account for most of the variance explained by any of these equations.

\section{Related Firm Operations and Affiliate Exports}

Our main interest is not in explanations of affiliate trade by size and openness, but in the extent and direction of any effects of same-firm operations in a host country on affiliate exports.

The "network" operations in a market that we consider consist of three parts. One is the MNC's production in that market, proxied by the net sales of the MNC's affiliates in that market, net sales being defined as total affiliate sales minus the affiliate's imports from the United States. The influence of related affiliate production could be both positive and negative. It could be positive to the extent that the producing affiliates import parts and components for their production from related Asian affiliates of their MNCs or that they open the local market to parts of their firms' product lines that they do not produce themselves. The effect on Asian affiliate exports could be negative to the extent that the destination region affiliate production substitutes for output that would otherwise be imported from the 
Asian affiliates.

The second MNC activity is exports by the U.S. parent to its affiliates in that market and the third is exports by the U.S. parent to unaffiliated purchasers in that market. Both types of parent exports could substitute for exports by the Asian affiliates of these firms. Parent exports to nonaffiliates are presumably finished products and more likely to be substitutes for Asian affiliate exports. Parent exports of parts and components could substitute for similar exports also by the Asian affiliates but could also imply that the importing affiliates are not self-contained, are integrated into the MNCs trading network, and therefore represent a market for the Asian affiliates. The full set of variables is:

$\operatorname{AFFEX}(I J K L)$ - Exports by Asian affillate I of MNC(J) in affillate industry $K$ to market region $\mathrm{L}$

POP(L) - Population of market region $L$

RGDP(L) - Real GDP in international prices

CNGDP(L) - Nominal GDP per capita in market region L

CRGDP(L) - Real GDP per capita in market region L

IMP(KL) - Total imports of industry $\mathrm{K}$ products into market region $\mathrm{L}$

NS(JL) - Net sales (sales minus imports from the U.S.) of all affiliates of $M N C(J)$ in market region $L$

PEXAF(JL) - Exports by the U.S. parent company of MNC(J) to all MNCJ's affillates in market region $\mathrm{L}$

PEXUN(JL) - Exports by the U.S. parent company of MNC(J) to all unaffiliated purchasers in market region $\mathrm{L}$

The results of fitting several equations to the data for the full set of Asian affiliates are given in Table 2. 
Table 2

Equations Explaining Exports to a Region by a U.S.-owned Asian Affiliate by Region Characteristics and Related MNC Operations

\begin{tabular}{|c|c|c|c|c|c|c|c|c|c|}
\hline \multirow{2}{*}{$\begin{array}{l}\text { Eq. } \\
\text { No. }\end{array}$} & \multicolumn{7}{|c|}{ Independent Variables } & \multirow{2}{*}{$\begin{array}{l}\text { Constant } \\
\text { Term }\end{array}$} & \multirow[b]{2}{*}{$\overline{\mathbf{R}}^{2}$} \\
\hline & $\mathrm{POP}(\mathrm{L})$ & CNGDP(L) & $\operatorname{RGDP}(\mathrm{L})$ & $\operatorname{IMP}(\mathrm{KL})$ & NS (JL) & $\operatorname{PEXAF}(\mathrm{JL})$ & $\operatorname{PEXUN}(\mathrm{JL})$ & & \\
\hline $2-1$ & $\begin{array}{r}4.53 \\
(2.2)\end{array}$ & $(0.3)$ & & $\begin{array}{r}3.36 \\
(2.7)\end{array}$ & $\begin{array}{l}-3.51 \\
(1.2)\end{array}$ & $\begin{array}{l}75.0 \\
(7.6)\end{array}$ & $\begin{array}{r}-14.5 \\
(2.4)\end{array}$ & $\begin{array}{l}616 \\
(0.1)\end{array}$ & .162 \\
\hline $2-2$ & $\begin{array}{r}4.11 \\
(3.2)\end{array}$ & & & $\begin{array}{r}3.39 \\
(2.8)\end{array}$ & $\begin{array}{l}-3.46 \\
(1.2)\end{array}$ & $\begin{array}{l}75.2 \\
(7.6)\end{array}$ & $\begin{array}{r}-14.4 \\
(2.4)\end{array}$ & $\begin{array}{l}345 \\
(0.2)\end{array}$ & .163 \\
\hline $2-3$ & & & $\begin{array}{r}2.14 \\
(2.8)\end{array}$ & $\begin{array}{r}2.37 \\
(1.8)\end{array}$ & $\begin{array}{l}-3.73 \\
(1.3)\end{array}$ & $\begin{array}{l}76.2 \\
(7.7)\end{array}$ & $\begin{array}{r}-14.3 \\
(2.4)\end{array}$ & $\begin{array}{r}1,267 \\
(0.5)\end{array}$ & .158 \\
\hline $2-4$ & & & & $\begin{array}{r}4.04 \\
(3.3)\end{array}$ & $\begin{array}{l}-3.87 \\
(1.3)\end{array}$ & $\begin{array}{l}79.1 \\
(8.0)\end{array}$ & $\begin{array}{r}-13.9 \\
(2.3)\end{array}$ & $\begin{array}{l}3,275 \\
\quad(1.8)\end{array}$ & .147 \\
\hline
\end{tabular}

No. of Observations: 499

$t$-statistics in parentheses 
Larger market region population or real GDP and larger market region imports of the products of an affiliate's industry are always positive influences on affiliate exports. Parent exports to their own affiliates in a market are positively related to their Asian affiliates' exports to that market. Parent exports to non-affiliates in a market seem to compete with the Asian affiliate exports. However, the positive coefficient for parent exports to affiliates is far larger than the negative coefficient for arms-length exports. The effect of production in a market by affiliate siblings within an MNC network is not clear: the coefficient is always negative, but never statistically significant.

Per capita nominal income in a market, included in equation $2-1$, has no significant effect on affiliate exports. If we drop that variable, as in equation 2-2, the coefficients of the other variables are virtually unchanged. If we substitute a measure of real GDP in the market region for the population, as in equation 2-3, the coefficient for aggregate imports into the region of the products of the affiliate's industry becomes insignificant, although it hardly changes in size.

If we omit all region characteristics other than MNC operations from the equation, we lose a little explanatory power but again find (equation 2-4) that industry imports into and parent exports to a host region are positively and significantly related to Asian affiliate exports, parent exports to nonaffiliates are negatively and significantly related to them, and the coefficient for related affiliate production is negative but not statistically significant.

Since the size of the market is taken into account in these equations, the level of an MNCs' affiliate net sales and exports to non-affiliates in a 
market represents the MNC's market share. That share may be supplied in many different ways. One is by local production (affillate net sales). Another is by a combination of parent and affiliate exports to or through related affiliates in the market. And a third is by parent exports to non-affiliates. The larger the share of non-manufacturing, as compared to manufacturing, affiliate operations controlled by the MNC in a market, the more dependent that market share will be on exports to the market by the parent and by the MNC's affiliates elsewhere. A large manufacturing operation controlled by the MNC could conceivably substitute for exports by the parent and its affiliates, but does not seem to do so to any significant extent. A lack of nonmanufacturing operations in a market, such as service or sales facilities, might reduce both parent exports to affiliates in that market and exports to that market by the MNC's affiliates in other countries.

\section{Astan Affillate Exports In Individual Industries}

It is conceivable, or even probable, that the role of affiliates, and in particular the way they fit into their MNC's allocation of production, could vary across industries. It would, therefore, be desirable to examine these relationships in individual industries. Our ability to do that is limited by the concentration of affiliates mentioned earlier, but we are able to perform similar calculations for two industries, Electronic Components and Accessories (ECA), and Office and Computing Machinery (OCM).

The equations (3-1 and 3-2) for Electronic Components and Accessories in

Table 3 explain a larger share of the variability of Asian affiliate exports in that industry that the equations for all industries, pooled, in Tables 1 and 2. The country's openness, or demand for this industry's products, as 
Table 3

Equations Explaining Exports of Electronic Components and Accessories and Office and Computing Machinery to a Region by a U.S. -Owned Asian Affiliate

\begin{tabular}{|c|c|c|c|c|c|c|c|c|}
\hline \multirow{2}{*}{$\begin{array}{l}\text { Eq. } \\
\text { No. }\end{array}$} & \multicolumn{6}{|c|}{ Independent Varlables } & \multirow{2}{*}{$\begin{array}{c}\text { Constant } \\
\text { Term }\end{array}$} & \multirow[b]{2}{*}{$\overline{\mathbf{R}}^{2}$} \\
\hline & POP (L) & $\operatorname{RGDP}(\mathrm{L})$ & $\operatorname{IMP}(\mathrm{KL})$ & NS (JL) & $\operatorname{PEXAF}(J L)$ & $\operatorname{PEXUN}(\mathrm{JL})$ & & \\
\hline \multicolumn{9}{|c|}{ Electronic Components and Accessorles } \\
\hline $3-1$ & & & $\begin{array}{l}7.01 \\
(1.6)\end{array}$ & $\begin{array}{l}7.7 \\
(.8)\end{array}$ & $\begin{array}{r}111.4 \\
(5.4)\end{array}$ & $\begin{array}{r}-20.8 \\
(1.3)\end{array}$ & $\begin{array}{r}-443 \\
(.1)\end{array}$ & .247 \\
\hline $3-2$ & $\begin{array}{l}11.7 \\
(2.6)\end{array}$ & & $\begin{array}{r}-3.41 \\
(.6)\end{array}$ & $\begin{array}{l}16.8 \\
(1.7)\end{array}$ & $\begin{array}{l}99.1 \\
(4.8)\end{array}$ & $\begin{array}{r}-21.3 \\
(1.3)\end{array}$ & $\begin{array}{r}203 \\
(.0)\end{array}$ & .247 \\
\hline $3-3$ & & $\begin{array}{c}4.7 \\
(1.0)\end{array}$ & $\begin{array}{r}-3.45 \\
(.3)\end{array}$ & $\begin{array}{l}10.1 \\
(1.0)\end{array}$ & $\begin{array}{c}106.8 \\
(5.1)\end{array}$ & $\begin{array}{r}-20.7 \\
(1.3)\end{array}$ & $\begin{array}{r}-3,814 \\
(.6)\end{array}$ & .311 \\
\hline \multicolumn{9}{|c|}{ Office and Computing Machinery } \\
\hline $3-4$ & & & $\begin{array}{r}1.98 \\
(3.7)\end{array}$ & $\begin{array}{r}-65.4 \\
(2.3)\end{array}$ & $\begin{array}{l}70.4 \\
(1.8)\end{array}$ & $\begin{array}{r}283.8 \\
(.7)\end{array}$ & $\begin{array}{r}727 \\
(.1)\end{array}$ & .218 \\
\hline $3-5$ & $\begin{array}{l}5.1 \\
(.8)\end{array}$ & & $\begin{array}{r}1.99 \\
(3.7)\end{array}$ & $\begin{array}{r}-56.9 \\
(1.9)\end{array}$ & $\begin{array}{l}60.8 \\
(1.5)\end{array}$ & $\begin{array}{r}239.9 \\
(.5)\end{array}$ & $\begin{array}{r}4,577 \\
(.4)\end{array}$ & .423 \\
\hline $3-6$ & & $\begin{array}{c}3.5 \\
(1.0)\end{array}$ & $\begin{array}{l}1.76 \\
(3.0)\end{array}$ & $\begin{array}{r}-59.0 \\
(2.1)\end{array}$ & $\begin{array}{l}63.5 \\
(1.6)\end{array}$ & $\begin{array}{r}220.8 \\
(.5)\end{array}$ & $\begin{array}{r}-7,262 \\
(.6)\end{array}$ & .321 \\
\hline
\end{tabular}

No. of Observations

Electronic Components and Accessories: 150

Office and Computing Machinery: 60

$t$-statistics in parentheses 
represented by the import variable, has no influence on Asian affiliate exports to the country, and almost all the explanation is provided by the parent export variable. If the parents exports to a country are high, Asian affiliate exports in this industry are also high.

For Office and Computing Machinery, on the other hand, a country's general openness and demand for such machinery was the significant influence (Equations 3-3 and 3-4). Parent exports to both affiliates and non-affiliates in the country were positively, but not significantly related to Asian affiliate exports, but production in the market by affiliates of the same MNC did appear to substitute in some degree for such exports.

\section{Exports by Affiliates in Individual Countries}

Just as there could be differences among industries in the way in which affiliates are fitted into the MNCs' networks of trade, affiliates in different countries may play roles in those arrangements that exploit the countries' locational advantages or comparative advantages in production. For two Asian host countries to U.S.-owned affiliates, Singapore and Taiwan, we have 100 affiliates or more reporting exports by region, and can calculate country equations across all industries, corresponding to those of Table 3 for individual industries across all countries.

The equations for exports by affiliates in the two individual countries across industries do not fit as well as those across countries for individual industries, but there is, nevertheless, some consistency in the results (Table 4). Parent exports to affiliates are always a positive influence and parent exports to non-affiliates a negative influence, and the level of imports in the industry by a destination country is always a positive influence on Asian 
Table 4

Equations Explaining Exports to a Region by a U.S.-Owned Affiliate in Singapore or Taiwan

Independent Variables

Eq. POP(L) RGDP(L) IMP(KL) NS(JL) PEXAF(JL) PEXUN(JL)

Constant

Term

$\overline{\mathbf{R}}^{2}$

\section{Singapore}

4-1

$39.9 \quad 1.44$

60.9

$-9.84$

(3.6)

(1.1)

.090

(1.9) (.4)

4,363

(1.2)

4-2

8.21

30.1

1.01

57.6

$-11.81$

(1.5)

(.3)

(3.4)

(1.3)

-328
$(.1)$

.136

4-3

$\begin{array}{rrrrr}4.14 & 923 & 1.22 & 56.5 & -11.20 \\ (2.6) & (.4) & (.3) & (3.3) & (1.2)\end{array}$

$-2,909$

(.6)

\section{Taiwan}

4-4

$71.8 \quad-5.93$

10.91

$-12.85$

1,015

.143

(4.1)

(.8)

(1.0)

(.4)

$4-5 \quad-1.18$
$\quad(.8)$

$76.4 \quad-6.22$

10.98

$-11.78$

(4.2)

(1.6)

(.8)

(.9)

1,722

(.7)

4-6

-50.6
$(.5)$

77.9

$-6.00$

10.94

$-12.24$

(3.7)

(1.5)

(.8)

(.9)

1,998

(.7)

.120

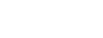

\section{No. of Observations}

Singapore: 175

Talwan: 101

t-statistics in parentheses 
affiliate exports. Exports by affiliates in Singapore are accounted for mainly by the country size and openness measures and by parent exports to affiliates in that market. Exports by affiliates in Taiwan are largely determined by country imports in that industry. Other variables do not have significant coefficients, although the signs of the coefficients are the typical ones.

\section{Affiliate Exports to Individual Regions}

Another possible source for differences in affiliate export behavior could be that related affiliate production and parent exports might play a different role in, for example, the UK or the EU countries from that in developing Asian countries. We attempt to test for that possibility, where we can, by separate regressions for those regions for which sufficient numbers of Asian affiliates report exports. If we set the lower limit at 60 observations, we eliminate six regions: Canada, the UK, Non-EU Europe, Latin America and Other Western Hemisphere, Africa, and the Middle East. The Equations of Table 5 are for the remaining regions, the European Union except the UK, Japan, and Asia and Pacific except Japan.

These equations do not explain a large part of the variation in affiliate exports to specific markets, but there is one striking consistency among the equations. That is that the coefficient for parent exports to affiliates is positive and significant, and that it is always substantially larger than the negative coefficient for parent exports to non-affiliates. A strong position of parent firms in exports to their own affiliates in a market, perhaps reflecting a strong position of the affiliates in the market, means that Asian affiliates of the same parents will tend to export more to 
Table 5

Equations Explaining Asian Affiliate Exports to Individual Regions of the World

\begin{tabular}{|c|c|c|c|c|c|c|c|}
\hline \multirow{2}{*}{$\begin{array}{l}\text { Eq. } \\
\text { No. }\end{array}$} & \multicolumn{4}{|c|}{ Independent Variables } & \multirow[b]{2}{*}{$\begin{array}{l}\text { Constant } \\
\text { Term }\end{array}$} & \multirow[b]{2}{*}{$\overline{\mathrm{R}}^{2}$} & \multirow[b]{2}{*}{$\begin{array}{l}\text { No. of } \\
\text { Obs. }\end{array}$} \\
\hline & $\operatorname{IMP}(\mathrm{KL})$ & NS (JL) & $\operatorname{PEXAF}(\mathrm{JL})$ & PEXUN (JL) & & & \\
\hline \multicolumn{8}{|c|}{ European Union, exc, U,K. } \\
\hline $5-1$ & $\begin{array}{r}2.91 \\
(1.1)\end{array}$ & $\begin{array}{r}-17.2 \\
(1.6)\end{array}$ & $\begin{array}{l}75.7 \\
(2.9)\end{array}$ & $\begin{array}{r}-20.8 \\
(2.0)\end{array}$ & $\begin{array}{r}6,793 \\
(.8)\end{array}$ & .108 & 62 \\
\hline \multicolumn{8}{|c|}{ Japan } \\
\hline $5-2$ & $\begin{array}{r}-7.91 \\
(.2)\end{array}$ & $\begin{array}{l}3.13 \\
(.2)\end{array}$ & $\begin{array}{l}29.4 \\
(2.5)\end{array}$ & $\begin{array}{r}-7.1 \\
(.9)\end{array}$ & $\begin{array}{r}4,184 \\
(2.0)\end{array}$ & .038 & 74 \\
\hline \multicolumn{8}{|c|}{ Asia and Pacific, exc, Japan } \\
\hline $5-3$ & $\begin{array}{l}2.09 \\
(.5)\end{array}$ & $\begin{array}{l}1.06 \\
(.2)\end{array}$ & $\begin{array}{r}113.2 \\
(5.3)\end{array}$ & $\begin{array}{r}-7.7 \\
(.5)\end{array}$ & $\begin{array}{r}7,320 \\
(.6)\end{array}$ & .149 & 158 \\
\hline
\end{tabular}

t-statistics in parentheses 
those markets. Large parent exports to non-affiliates in a market, however, may be competing to some extent with exports to that market by the parent's Asian affiliates, or they might reflect a weak position of the parent's affiliates in that market.

\section{Conclustons}

Various combinations or slices of the data on exports to individual regions by Asian affiliates of U.S. MNCs, offer a few fairly definite and some very tentative conclusions. Network or "family" connections within an MNC improve export market entry and market share possibilities in individual markets for the MNC's affiliates located in Asian countries. The strongest and most consistent impact is that in cases (firms and markets) where parents export more to their affiliates, the Asian affiliates of these parents also export more to these markets. Higher parent exports to non-affiliates are associated with lower exports to the same markets by the parents' Asian affiliates, but that effect is much smaller per dollar of parent exports and not consistently significant. Production in a market by an affiliate of a parent is weakly, almost never significantly, associated with lower exports by the parent's Asian affiliates. One way of interpreting the opposite signs of the coefficients for parent exports to affiliates and non-affiliates is that higher parent exports to affiliates in a market reflect a strong position in that market for the MNC's affiliates, and that that strength is helpful to other affiliates of that MNC, such as the Asian affiliates, in penetrating the market. Relatively high parent exports to non-affiliates in a market reflect a weak position for the MNCs affiliates in that market, and relatively poor conditions for the MNCs affiliates in other countries to export to that 
market.

The strongest relationships we found for Asian affiliate exports were within two individual industries, Electronic Components and Accessories, and office and Computing Machinery. The equations for the latter industry were unusual in that the negative coefficients for affiliate production were statistically significant in a couple of cases and the coefficients for parent exports to non-affillates were positive and large, although not statistically significant. Perhaps in this industry, in contrast to others, parent exports even to non-affiliates encouraged Asian affiliate exports to the same markets.

\section{$\underline{\text { Reference }}$}

U.S. Department of Commerce (1992), U.S. Direct Investment Abroad. 1989

Benchmark Survey, Final Results, Bureau of Economic Analysis, Washington, DC, U.S. Government Printing Office, October. 